\title{
The Effect of COVID-19 Pandemic on the Frequency of Domestic Flights
}

\author{
Ertan Çınar ${ }^{1}$ \\ ORCID: 0000-0002-7783-4770
}

\author{
Metin Özgür ${ }^{2}$ \\ ORCID: 0000-0003-1023-0064
}

\begin{abstract}
The objective of this study is to reveal with different variables the relationship between the frequency of domestic flights of airline passengers in Turkey and the number of daily patients, which is a COVID-19 pandemic data. The data collection tool used in the study is a questionnaire. A correlation test was used in the analysis of the relationship between the annual flight frequency before and after the pandemic (Considering the pandemic is over). Hypotheses on the changes in flight frequency were developed with the demographic data, and these hypotheses were tested by one-way ANOVA method. SPSS 22 program was used to analyze the data. 229 people participated in the survey, and among them 202 eligible people were included in the study. The results of the correlation test were determined to be significant. It is revealed that there is a relationship between the declared number of patients and the flight frequency. As the declared number of patients increases, the flight frequency decreases. A decrease by a maximum of $82 \%$ is predicted in the average annual flight frequency per person if the patient number is estimated to be over 3000. All of the socio-demographic variables studied, except the level of education, affect flight frequency.
\end{abstract}

Keywords: Air transportation, questionnaire, COVID-19, flight frequency, passenger.

\footnotetext{
${ }^{1}$ Asts. Prof., Eskişehir Teknik Üniversitesi, E-mail: ecinar@eskisehir.edu.tr

${ }^{2}$ Asts. Prof., Eskişehir Teknik Üniversitesi, E-mail: mozgur4@eskisehir.edu.tr

idealkent @ Kent Araştırmaları Dergisi (Journal of Urban Studies) 


\section{Covid-19 Pandemisinin İç Hatlardaki Uçuş Sıklığına Etkisi}

\author{
Ertan Çınar ${ }^{3}$ \\ ORCID: 0000-0002-7783-4770
}

\author{
Metin Özgür ${ }^{4}$ \\ ORCID: 0000-0003-1023-0064
}

\section{Öz}

Bu çalışmanın amacı yolcuların görüşlerine dayalı olarak Türkiye'deki hava yolu yolcularmın yurt içinde (iç hatlar) gerçekleştirecekleri uçuş sıklıklarının COVID-19 pandemi verilerinden olan günlük hasta sayıları ile olan ilişkisini çeşitli değişkenlerle birlikte ortaya çıkarmaktır. Araştırmada kullanılan veri toplama aracı ankettir. Pandemi öncesi ile sonrası arasındaki yıllık uçuş sıkliğı ilişkisinin analizinde korelasyon testi uygulanmıştır. Ayrıca demografik verilerle uçuş sıklı̆̆ 1 değişimine dair hipotezler oluşturulup bu hipotezler tek yönlü ANOVA yöntemi ile sinanmıştır. Verilerin analizinde ise SPSS 22 programından yararlanılmıştır. Ankete 229 kişi katılmış fakat bunların arasından sadece uygun olan 202 kişi değerlendirmeye alınmıştır. Korelasyon test sonuçları anlamlı çıkmıştır, dolayısıyla çeşitli zaman periyodları için verilmiş olan tahmini ortalama hasta sayıları ile uçuş sıklıkları arasında bir ilişki tespit edilmiştir. Bildirilen hasta sayısı arttıkça uçuş sıklığının azaldığı görülmüsstür. Hasta sayısı 3000'in üzerinde olduğunda, kişi başına ortalama yıllık uçuş sıklığında en fazla \%82'lik bir azalma öngörülmektedir. Incelenen sosyo-demografik değişkenlerden eğitim düzeyi haricindekilerin tamamının uçuş sıklı̆̆ını etkilediği ortaya çıkmıştır.

Anahtar Kelimeler: Hava taşımacılığı, anket, COVID-19, uçuş sıklı̆̆l, yolcu.

\footnotetext{
${ }^{3}$ Dr.Öğr.Üyesi, Eskişehir Teknik Üniversitesi, E-mail: ecinar@eskisehir.edu.tr

${ }^{4}$ Dr.Öğr.Üyesi, Eskişehir Teknik Üniversitesi, E-mail: mozgur4@eskisehir.edu.tr

idealkent @ C Kent Araştırmaları Dergisi (Journal of Urban Studies) 


\section{Introduction}

Passenger transportation by air is the fastest method of transportation today and is therefore preferred the most. However, the air transport sector is easily affected by crises. These crises, the main reasons of which stand out as economy, war, health issues and terrorism, inflict major financial blows on airline enterprises. If the major crises that have affected the air transportation system or that have started within the system in the last fifty years are analyzed, it is seen that there has been a total of eight crises in the sector:

- 1974 Oil Crisis (October 1973-March 1974)

- 1980 Iran-Iraq War (September 1980 - August 1988)

- 1991 Gulf Crisis (August 1990- February 1991)

- 1998 Asian Crisis (July 1997-1999)

- 2001 September 11 Crisis (September 2001)

- 2002 SARS Crisis (November 2002- July 2003)

- 2008 World Economic Recession (2008-2012)

- 2020 COVID-19 Crisis (November 2019 -...)

One of these crises, the 2008 recession is compared with the world depression of 1929 in the sense of "economic depression". Another comparison is made between the COVID-19 crisis, which the world has been experiencing recently and the Spanish Flu, experienced between 1918-1920. However, no comparison can be made regarding the air transport system in either of these two crises.

Among the crises mentioned above, the 1998 Asian crisis and the crises in the following period had a huge impact on the air transport system. In the Asian crisis, a decrease of approximately $15 \%$ in freight tonne per kilometer (FTK) and a decrease of approximately $5 \%$ in revenue passenger kilometers (RPK) were observed according to GDP of the world compared to the values of the previous year. In the September 11 crisis in 2001, the situation became much worse and the growth fell to a negative direction because of a big contraction. Although the SARS crisis was effective in cargo transportation in general, the growth in passenger transportation continued. The recession that started in 2008 negatively affected both the GDP in the world and the air transport sector (ICAO, 2020). Thus, these crises mentioned above have damaged the profitability of the air transport system.

The prediction made by ICAO for the effect of the pandemic we have been experiencing today is that the number of international passengers transported in 2020 will decrease to the data of 2003 (ICAO, 2020). 
The pandemic has had a great shock all over the world and in all sectors, especially the aviation industry (Suau-Sanchez, Voltes-Dorta, \& Cugueró-Escofet, 2020). Many airlines have grounded their planes and closed their lines (Sun, Wandelt, \& Zhang, 2020). In addition, many airports have been closed to flights and have become aircraft parking areas (Adrienne, Budd, \& Ison, 2020). The situation is worst for passengers who have to travel by air during the pandemic. Considering only the flight, passengers spend most of their time in closed cabins and away from social distance (Sun, Wandelt, Zheng, \& Zhang, 2021).

Since the liberalization of domestic flights in Turkey after 2003 many flight lines have been opened and the domestic passenger traffic has increased exponentially (Gerede, 2015, p.194). However, there has been a recession in the airline passenger transportation due to some causes such as measures, restrictions and illness anxiety etc. of COVID-19 pandemic for over than a year both all around the world and in Turkey.



First Ten Months of the Year

Figure 1. Domestic passenger traffic between 2008 and 2020 in Turkey (between January and October, 10 months). (This Figure was compiled and created by autors from İstatistikler, 2020)

The total number of 10-month domestic passengers per year between 2008 and 2020, from the beginning of the year to October, is shown in Fig. 1. (Since the statistics of October were last declared at the time of the study, the data from the beginning of each year to October were compared). As it can be understood from this chart, while the numbers of passengers were constantly increasing until 2019, a sudden decrease occurred in 2019 when the COVID- 
19 pandemic occurred, and this decrease increased until October 2020 and fell to the level of passenger numbers of 10 years ago.

The demand for flights will be affected as long as the pandemic continues, and even if the pandemic ends, it may take some time to return to its previous level as well because the pandemic has affected people's lifestyles, working styles, economic status and psychology (Di Renzo et al., 2020). There are also uncertainties associated with the escalation and recurrence of the pandemic, which causes problems related to anxiety and distrust. In order to predict how much this latest crisis will affect the airline transportation sector, not only the course of the pandemic but also the perspective of the passengers, who are customers of this sector, on air travel and their decisions on this issue will be the determining factors.

The overall aim of this study is to predict how this pandemic will affect the flight demand in the future by asking the passengers' opinions. In addition to this, the effects of various variables will also be examined.

There are many factors that can affect passengers' flight decisions. The measures taken against the pandemic, confidence in their effectiveness, restrictions, increases in ticket prices, the disappearance of travel reasons (e.g., tourism, business, education, festival, fair, competition, concerts etc.), the number of cases, and the number of patients etc. can affect their decisions.

It is seen that the number of cases is approaching 68 million in the world and is constantly increasing as of mid-December 2020 (WHO, 2020). The number of patients per day is one of the factors that show the greatest variability regarding the pandemic, and this number is thought to be effective in evaluating the effectiveness of the measures and therefore in people's perception of the risk ratio and the increase-decrease of the risk. For this reason, the number of daily patients is considered to be the main variable related to the pandemic in this study. Because the target population of the study is composed of passengers of domestic flights in Turkey, the number of daily patients that are supposed to have been declared by Turkish Ministry of Health is used in the study. The research questions of the study are as follows: "Is there a relationship between the number of daily patients (750-3000) and the flight frequencies to be planned in the future (6 and 12 months)? How will flight frequencies change depending on the number of patients?". The hypotheses of the study are about the existence of relationships between demographic variables, the numbers of daily patients and the flight frequencies to be planned in the future. Other parameters that could influence decisions have been neglected. 
The study is thought to have particular importance since there is no other study in this scale with this method and within this time period. It is also thought to be important to predict how the future flight demand will change and to provide a supportive input for the airline companies to make their plans accordingly.

\section{Background and literature review}

Huge number of studies have been conducted about effects of COVID-19 on air transportation industry in various aspects. There is a big review collecting the studies in various headings (Sun, et al., 2021). But there are a few studies based on questionary related to prediction of air travel demand, to date.

The most similar and the only study conducted on the effect of the Covid19 pandemic on flight demand was conducted in the earlier stages of the pandemic (in April) when it started to appear in Turkey. In the study, in which the purposeful sampling method was used, Özdemir and Ylldız (2020) aimed to examine the effects of the COVID-19 pandemic on travel intentions of tourists in Turkey. A "semi-structured" question form was used to collect data in this study, which had the characteristics of an exploratory research. The sampling of the study consisted of 62 potential tourists, who live in Turkey and who are in the habit of travelling at least once a year before the outbreak.

As for the studies regarding the impact of the Covid-19 pandemic on flight frequency abroad, there is a questionnaire study, the third of which was conducted in July 2020 by IATA (International Air Transport Association) (Rockland, 2020). This questionnaire was conducted on 4700 passengers from 11 countries (Australia, Canada, USA, UK, France, Germany, UAE, India, Japan, Singapore, and Chile).

A survey with 632 participants from United States was conducted in order to predict which type of person would be willing to fly during and after the COVID-19 pandemic (Lamb, Winter, Rice, Ruskin, \& Vaughn, 2020). It explores 23 predictors under 4 categories of demographics, personality measures, emotional states and travel purposes so as to develop a descriptive regression equation and a predictive model. A study conducted with similar aim based on 760 questionnaires in Taiwan, too (Lin \& Zhang, 2021).

In another study based on interviews with senior executives of the industry in aviation in the first weeks of the pandemic, the effects of the pandemic on the aviation industry in the medium and long term were investigated (Suau-Sanchez et al., 2020). 
Apart from the survey-based studies mentioned above, an example of other predictive studies on the demands in the future is a study in which Big Data based on passenger searches on Skyscanner is used (Gallego \& Font, 2020). In this study, various results related to how much the desire and intention to travel will decrease in different continents have been obtained. Another study predicts that the demand will decrease because the companies that have gone bankrupt due to the pandemic will affect other connected flights with a chain reaction (Ye, 2020). They predicted the decrease in demand based on the traffic data in the Official Aviation Directory and on their simple assumptions about the customers' selection strategies for airline company. With the calculation methods they developed, they tried to estimate how much these decreases would affect the traffic. Another study estimates recovery time of worldwide passenger demand to preCOVID-19 levels (Gudmundsson, Cattaneo ,\& Redondi, 2021b).

\section{Materials and methods}

\section{Data Collection Method}

The data collection tool used in the study is a questionnaire. This questionnaire consists of a total of 14 statements, 6 of which are about socio-demographic information. The statements about socio-demographic information are as follows: age, gender, education level, income level, purpose of air travel, person who covers the travel expenses. The other statements are the ones that are asked for annual flight frequency and whose answers are received as direct numerical values. In one of them, the pre-pandemic annual flight frequency is asked, while in the others, annual flight frequencies based on the declared number of patients in 6and 12-month time periods in the future as of today are asked. 4 values such as "over 3000", "average 1500", "below 750" and "0" are taken as the bases of the study because they are close to today's values and are likely to be encountered in 6 and 12-month time periods.

These questionnaires were shared on various social media platforms in October 2020 to be filled in on the online platform and the results were evaluated at the end of the same month.

\section{Statistical Analysis}

For the statistical analysis, frequencies and percentages were calculated for the demographic variables. Percentages, standard deviations and averages of the responses to flight frequencies varying according to demographic data 
were calculated. The correlation test was used in the analysis of the annual flight frequency relationship between before and after the pandemic and Pearson correlation coefficient was used. The hypotheses related to the variation in flight frequency according to demographic data were developed and these hypotheses were tested with the one-way ANOVA method, which is used in testing the differences between more than two groups. The SPSS 22 program was used to analyze the data.

\section{Results}

229 people participated in the online questionnaire, and 202 responses were evaluated because those who did not fly before the pandemic were eliminated. The results of demographic findings, key findings, correlation test and hypothesis test are given below.

\section{Demographic Findings}

As can be seen from Table 1 a total of 202 people participated in the study. While 132 of them are males, 70 of them are females. As a percentage, 65.3\% of the participants are males, whereas $34.7 \%$ are females. Considering the educational status of the participants, 6 persons are secondary school graduates, 5 persons are high school graduates, 142 persons are university graduates, 31 persons are master's graduates, and 23 persons are $\mathrm{PhD}$ graduates. Considering the percentage distribution of the educational status of the participants, $2.5 \%$ are high school graduates, $70.3 \%$ are university graduates, $15.3 \%$ are master's graduates, and $11.4 \%$ are $\mathrm{PhD}$ graduates. This indicates that the majoritiy of the respondents had a high level of education. When the income groups of the participants are examined, the income of 32 participants is below $4.000 \mathrm{TL}$, the income of 52 participants is between 4.001- $8.000 \mathrm{TL}$, the income of 57 participants is between 8.001-12.000 TL and 61 participants have an income of over $12.001 \mathrm{TL}$. If the income status of the participants is expressed as a percentge, $15.8 \%$ has an income below $4.000 \mathrm{TL}, 25.7 \%$ has an income range between 4.001 and $8.000 \mathrm{TL}, 28.2 \%$ has an income between 8.001 and $12.000 \mathrm{TL}$ and $30.2 \%$ has an income of over $12.001 \mathrm{TL}$. More than $50 \%$ of the respondents are from the income group of $8.001 \mathrm{TL}$ and above. 
Table 1. Demographic distribution of the respondents

\begin{tabular}{|c|c|c|c|}
\hline & & $\begin{array}{l}\text { Numbers of } \\
\text { respondents }\end{array}$ & $\begin{array}{l}\text { Percentages of } \\
\text { respondents (\%) }\end{array}$ \\
\hline & Total & 202 & 100 \\
\hline \multirow{2}{*}{ A1. Gender } & Male & 132 & 65,3 \\
\hline & Female & 70 & 34,7 \\
\hline \multirow{4}{*}{$\begin{array}{l}\text { A2. Level of } \\
\text { education }\end{array}$} & $\begin{array}{l}\text { Secondary education (High } \\
\text { school+secondary school) }\end{array}$ & 6 & 3 \\
\hline & Undergraduate education & 142 & 70,3 \\
\hline & Master's & 31 & 15,3 \\
\hline & Doctorate & 23 & 11,4 \\
\hline \multirow{7}{*}{ A3. Age } & $18-26$ & 25 & 12,4 \\
\hline & $27-34$ & 49 & 24,3 \\
\hline & $35-42$ & 53 & 26,2 \\
\hline & $43-50$ & 40 & 19,8 \\
\hline & $51-58$ & 19 & 9,4 \\
\hline & $59-64$ & 10 & 5 \\
\hline & 65 and over & 6 & 3 \\
\hline \multirow{4}{*}{ A4. Income } & Below $4.000 \mathrm{TL}$ & 32 & 15,8 \\
\hline & $4.001-8.000 \mathrm{TL}$ & 52 & 25,7 \\
\hline & $8.001-12.000 \mathrm{TL}$ & 57 & 28,2 \\
\hline & 12.001 and over & 61 & 30,2 \\
\hline \multirow{3}{*}{$\begin{array}{l}\text { A5. Purpose of } \\
\text { air travel }\end{array}$} & Education & 7 & 3,3 \\
\hline & Business & 46 & 22,7 \\
\hline & Touristic & 149 & 73,7 \\
\hline \multirow{3}{*}{$\begin{array}{l}\text { A6. Who covers } \\
\text { the travel expenses? }\end{array}$} & My family & 12 & 5,9 \\
\hline & My employer & 34 & 16,8 \\
\hline & I & 156 & 77,2 \\
\hline
\end{tabular}

\section{Key Findings on Flight Frequency}

The percentage (\%), average and standard deviation of the responses regarding annual flight frequencies varying according to demographic factors between A1 and A6 are calculated and given in Table 9 in the first column of the table gives the annual flight frequency values according to the changing number of patients and time period, and the first two rows give the options of the demographic categories.

The explanation of the codes of A7-A15 in the table is as follows:

- A7: How many times did you fly in a year before the pandemic? 
- A8: If the number of daily patients remains at the level of 1500 in the next 6 months, how many times will you fly in a year?

- A9: If the number of daily patients stays at 1500 in the next 12 months, how many times will you fly in a year?

- A10: If the number of daily patients exceeds 3000 in the next 6 months, how many times will you fly in a year?

- A11: If the number of daily patients exceeds 3000 in the next 12 months, how many times will you fly in a year?

- A12: If the number of daily patients falls below 750 in the next 6 months, how many times will you fly in a year?

- A13: If the number of daily patients falls below 750 in the next 12 months, how many times will you fly in a year?

- A14: If the pandemic is over now, how many times will you fly in the next 6 months?

- A15: If the pandemic is over now, how many times will you fly in the next 12 months?

Although many conclusions can be reached according to the findings presented in Table 9 in Appendix, the most important factor is that it reveals the change rate of annual flight frequencies of all participants of the questionnaire before, during and after the pandemic. This information is visualized in Fig. 2 below. There are two lines in this chart. One of the lines represents the numerical value of the average annual flight frequency and the percentage change per person according to 6-month estimated number of patients, whereas the other line represents the numerical value of the average annual flight frequency and the percentage change per person according to 12-month estimated number of patients. On the horizontal axis, the number of patients is given in periods starting with the pre-pandemic (PP), up to 750 patients, 1500 patients, 3000 or more patients, and the end of the pandemic respectively. The vertical axis, on the other hand, shows the annual flight frequency. According to this, it is seen that the average annual flight frequency per person was 5 before the pandemic, and it is predicted that there will be a decline up to an average of 1 annual flight frequency with a maximum $82 \%$ decrease as the number of patients increases, that there will be a big recovery with an $18 \%$ decrease based on 6-month data immediately after the pandemic, and that even pre-pandemic flight frequency will be exceeded (6\%) with an estimation based on 12-month data. In short, it is seen that flight frequencies decrease inversely proportional to the number of patients and that giving the 
data according to the number of patients in 6 or 12 months does not make much difference in flight frequencies.



$--\mathrm{O}-$ BASED ON 6 MONTHS DATA $\longrightarrow$ BASED ON 12 MONTHS DATA

Figure 2. The change rate of average annual flight frequencies per person in periods before, during and after the pandemic. (This figure created by the autors, 2021)

\section{Correlation Test}

In order to determine the relationship between the pre-pandemic flight frequencies of the passengers and their flight frequencies during and after the pandemic, the correlation test was used. The results of this test are given in Table 2 below. In order to evaluate the results of the correlation tests to be statistically significant, it is stated that there is a medium level relationship between $r=0.30-0.70$ and a high-level relationship between 0.71 and 0.99 (Büyüközlü, p.31, 2018.). In this context, according to the test results, it is seen that when the number of patients is zero after the pandemic, $r>0.644$ within 6 months and $r>0.785$ after 12 months for the participants, who made domestic flights before the pandemic. It is also seen that the participants tend to maintain their annual flight frequency before the pandemic. On the other hand, if the pandemic continues in the next 6 months (regardless of the number of patients), it is observed that there is a low relationship between the participants' pre-pandemic flight frequencies and their flight frequencies in the future. As a result of this finding, it can be concluded that if the number of cases does not decrease, the frequency of flights in the following 1 year will decrease at a moderate level. 
Table 2 The results of the correlation test

\begin{tabular}{|c|c|c|c|c|c|c|c|}
\hline 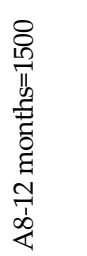 &  & 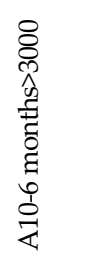 &  & 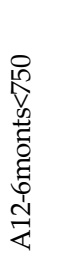 & 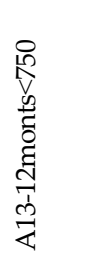 & 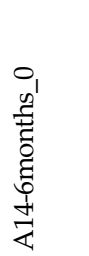 & 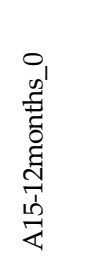 \\
\hline 0.33 & 0.332 & 0.31 & 0.312 & 0.408 & 0.388 & 0.644 & 0.785 \\
\hline
\end{tabular}

\section{Tests of Hypotheses}

The following hypotheses are tested within the framework of the study: Ha0: There is no difference between the males and females in terms of flight frequency.

$\mathrm{Hb} 0$ : There is no difference between the education levels in terms of flight frequency.

Hc0: There is no difference between the age groups in terms of flight frequency.

Hd0: There is no difference between the income levels in terms of flight frequency.

$\mathrm{He} 0$ : There is no difference between the purposes of air travel in terms of flight frequency.

Hf0: There is no difference between the persons who cover the expenses in terms of flight frequency.

The one-way ANOVA method is used in the analysis of these differences. The p significance level is determined as $5 \%$. 
Table 3 Change in flight frequency according to gender

\begin{tabular}{lll}
\hline A1_gender & & P value \\
\hline A8-12 months=1500 & 1 Male & 0,32 \\
A9-6 months $=1500$ & 2 Female & 0,26 \\
& 1 Male & 0,68 \\
A10-6 months $>3000$ & 2 Female & 0.59 \\
& 1 Male & 0.11 \\
A11-12 months $>3000$ & 2 Female & 0.10 \\
A12-6 months $<750$ & 1 Male & 0.82 \\
A13-12 months $<750$ & 2 Female & 0.71 \\
& 1 Male & 0.92 \\
A14-6 months_0 & 2 Female & 0.64 \\
& 1 Male & 0.29 \\
A15-12 months_0 & 2 Female & 0.25 \\
& 1 Male & 0.10 \\
& 2 Female & 0.11 \\
\hline
\end{tabular}

The $\mathrm{p}$ values for the change of flight frequency according to gender are given in Table 3. Accordingly, the Ha0 hypothesis is rejected because $\mathrm{p}<0.05$ for the variable A15. When the averages are examined, it is seen that this difference is caused by "female" participants because they have a lower average. During the pandemic, females tend to fly less. The vast majority of males and females who answered the questionnaire stated that they fly for touristic purposes. When the Table 9 in Appendix is analyzed, it is seen that the average of the answers given by the females participating in the questionnaire is lower than that of the males.

When the relationship between the change in flight frequency and education level is analyzed, it is seen that there is no statistically significant difference between the groups according to the education levels of the participants at $\mathrm{p}<0.05$ level of significance. When the averages in Table 9 in Appendix are analyzed, it is seen that secondary education graduates can be regarded as the most important reason for this situation because they tend to fly even if there is a pandemic. As it can be seen in Table 4, this value is seen to be higher than 0.05 for each row. Therefore, the $\mathrm{Hb} 0$ hypothesis is accepted. 
Table 4 The change in flight frequency according to education level

\begin{tabular}{ll}
\hline A2_Education & $(p)$ value \\
\hline A8-12 months $=1500$ & .288 \\
A9-6 months $=1500$ & .565 \\
A10-6 months $>3000$ & .726 \\
A11-12 months $>3000$ & .563 \\
A12-6 months $<750$ & .117 \\
A13-12 months $<750$ & .112 \\
A14-6 months_0 & .511 \\
A15-12months_0 & .370 \\
\hline
\end{tabular}

$79.6 \%$ of university graduates travel for touristic purposes. $40.7 \%$ of higher education graduates prefer domestic air travel for business travel. $57.4 \%$ of the same group fly for touristic purposes. Secondary education graduates made an average of 4.7 flights a year before the pandemic. Secondary education graduates come to this flight average in A12, while university graduates and higher education graduates come to this average if the pandemic is over.

The $\mathrm{p}$ values for the change of flight frequency according to age are given in Table 5. When the age groups are analyzed in different variations such as 18-34 and 35-65+, it is seen that the differences emerge. It can be concluded that the group under the age of 35 tends to fly more during the pandemic period compared to the other age group.

It is seen that there was no significant difference in flight frequencies in terms of age groups before the pandemic. As it can be understood from the $p$ value which is less than 0.05 in Table 5, it can be said that the difference between them is not significant. In this case, the Hc0 hypothesis is rejected. However, if the pandemic ends today, it can be said that all groups will tend to fly in the next 12 months.

Table 5 The change in flight frequency according to age

\begin{tabular}{ll}
\hline A3_Age & $(p)$ value \\
\hline A8-12 months $=1500$ & .003 \\
A9-6 months $=1500$ & .000 \\
A10-6 months $>3000$ & .015 \\
A11-12 months $>3000$ & .016 \\
A12-6 months $<750$ & .003 \\
A13-12 months $<750$ & .006 \\
A14-6 months_0 & .016 \\
A15-12months_0 & .083 \\
\hline
\end{tabular}


The $\mathrm{p}$ values for the change of flight frequency according to income level are given in Table 6. considering the income levels of the respondents of the questionnaire, if the pandemic ends today, people with an income group of 12,001 TL and above will have more flight tendency than people with lower income. Although the flight frequency of the people in the group with an income level of 8000-12000 TL was similar to that of the people in the group with an income level of over 12.001 TL before the pandemic, the flight frequency will differ in the group with an income group of $12.001 \mathrm{TL}$ if the pandemic ends. In this case, the HdO hypothesis is rejected. Regardless of the income level, if the pandemic is over, the participants of the questionnaire will tend to return to their pre-pandemic flight frequency.

Table 6. The change in flight frequency according to income level

\begin{tabular}{ll}
\hline A4_Income level & $(p)$ value \\
\hline A8-12 months $=1500$ & .990 \\
A9-6 months $=1500$ & .966 \\
A10-6 months $>3000$ & .126 \\
A11-12 months $>3000$ & .110 \\
A12-6 months $<750$ & .839 \\
A13-12 months $<750$ & .859 \\
A14-6 months_0 & .008 \\
A15-12 months_0 & .000 \\
\hline
\end{tabular}

The $p$ values for the change of flight frequency according to purpose of travel are given in Table 7. Because the p value of A15-12 months_0 is less than 0.05 , it is not significant. Therefore, the He0 hypothesis is rejected. When the average flight frequency of this group is analyzed, it can be said that they will tend to make more flights.

The $\mathrm{p}$ values of the groups for the change of flight frequency according to the person who covers the expenses are given in Table 8 . Since the results are similar according to $\mathrm{p}<0.05$, Hf0 hypothesis is rejected. When the pandemic is thought to be over, it is seen that the participants of the questionnaire will tend to fly, regardless of the person who covers the expenses. It is also seen that people participating in the questionnaire generally do not tend to fly domestically during the pandemic, regardless of who covers the expenses. If the pandemic ends, the participants of the questionnaire will be able to return to their previous flight frequencies, regardless of who covers the expenses. When the average flight frequency according to the person who covers the expenses is analyzed in Table 9 in Appendix, this situation is observed. 
Table 7 The change in flight frequency according to purpose of travel

\begin{tabular}{ll}
\hline A5_purpose of travel & $(p)$ value \\
\hline A8-12 months $=1500$ & .564 \\
A9-6 months $=1500$ & .346 \\
A10-6 months $>3000$ & .607 \\
A11-12 months $>3000$ & .789 \\
A12-6 months $<750$ & .205 \\
A13-12 months $<750$ & .633 \\
A14-6 months_0 & .102 \\
A15-12 months_0 & .014 \\
\hline
\end{tabular}

Table 8 The change in flight frequency according to the person who covers the expenses

\begin{tabular}{ll}
\hline A6 Person who covers the expenses & $(p)$ value \\
\hline A8-12 months $=1500$ & .990 \\
A9-6 months $=1500$ & .966 \\
A10-6 months $>3000$ & .126 \\
A11-12 months $>3000$ & .110 \\
A12-6 months $<750$ & .839 \\
A13-12 months $<750$ & .859 \\
A14-6 months_0 & .008 \\
A15-12months_0 & .000 \\
\hline
\end{tabular}

\section{Discussion}

The analyses performed within the scope of the study reveal that there is a decrease in the frequency of flights, depending on the size of the number of daily patients declared. It can be seen both in the correlation test and in the graph regarding the change of the averages. This decrease is observed to have reached up to $82 \%$. If the pandemic ends, it can be predicted that it will recover to the values of the previous flight frequencies even in the first year.

Although it is not possible to make one-to-one comparisons between the present study and the other studies in literature due to their different methods, materials, populations and samples, some of the findings obtained from this study can be compared to those of the other similar studies. According to the findings of a study conducted in Turkey in April (Özdemir \& Yıldız, 2020), it was revealed that the full recovery on flight demand process, which is predicted to be in the first year of pandemic's end in the our study, would most probably exceed three years even if the pandemic is over. The big difference between these two paper's findings can be related to the small size of the participant group, the difference in the research method and lack of generalizability of the samples in the other study. On the other hand, the results 
of an international study conducted by IATA in 11 countries indicate that only $12 \%$ of the passengers will start flights "immediately" even if the "pandemic is over (Rockland, 2020). 33\% of the participants stated that they would postpone their flights " 1 month after the pandemic", $36 \%$ of the participants stated that they would postpone their flights " 6 months later", $14 \%$ of the participants stated that they would postpone their flights " 1 year later", and $5 \%$ of the participants stated that they would not realize their normal flight plans for an indefinite period. The survey depicts that it is expected that $81 \%$ of demand can recover less than a year after the pandemic. It is close to the finding of the present study, which predicts that there will be a recovery of flight frequencies (or demand) to a great extent within 1 year in Turkey. Similarly, in another study, it is predicted that the demand will decrease in the medium and long term (Sanchez, et al 2020). The domestic demand was revealed to be lower than the average in another study (Galileo \& Font, 2020).

Methodology of Gudmundsson et al. is different than the present study. Firstly, it is not based on questionary; the scope is not Turkey based, instead it is worldwide; they use IATA and ICAO air traffic estimates; take into account different factors such as; specific restrictions on aviation, the blocking of international traffic and any future restrictions of aircraft and airport operations due to pandemic; and they use ARIMAX (Auto Regressive Integrated Moving Average) process of equation for their predictions based on gross domestic product, oil prices and traffic history. But their output type is a bit similar. They estimate recovery of worldwide passenger demand to pre-COVID19 levels is estimated to take 2.4 years (by late-2022), with the most optimistic estimate being 2 years (by mid-2022), and the most pessimistic estimate 6 years (in 2026) (Gudmundsson et al., 2021). However, another estimate depicts that passenger numbers might recover after 2024 ("Air traffic will take years to return to 2019 levels," 2020). If such models are feeded with the data gathered with our method, the accuracy of predictions may increase.

When the other analyses that are conducted on the relationship between the flight frequency in various time periods and the number of daily patients is analyzed according to demographic variables, the following results can be obtained from the present study:

- There is a statistically significant difference between gender groups in terms of flight frequency.

- There is no difference between the participants' education levels in terms of flight frequency. 
- There is a statistically significant difference between age groups in terms of flight frequency. In addition, if the pandemic is over, the frequency of flights can be expected to return to normal within 12 months. On the other hand in a survey conducted in Taiwan the passengers under the age of 20 have higher tendency to fly during a crisis like COVID-19 pandemic, but the frequency of their flights are not predicted in the survey (Lin \& Zhang, 2021). It is all about their motivation.

- There is a statistically significant difference between income groups in terms of flight frequency.

- There is a statistically significant difference between the purposes of travel in terms of flight frequency. A significant difference was also predicted in another study (Suau-Sanchez et al., 2020).

- There is a statistically significant difference between the groups of persons who cover the travel expenses in terms of flight frequency.

According to a survey conducted in US it is identified that the willingness of people to fly during and after the pandemic varies, which is quite compatible with our findings listed above (Lamb et al., 2020). They don't predict the flight frequency, instead they predict the variance of flying willingness according to characteristics of these persons. They explored it among 23 factors: ethnicity, education level, age, gender, number of at-risk COVID-19 family members, current health level, level of religiousness, number of children, primary purpose of travel pre-coronavirus, pre-COVID-19 flight anxiety, perceived threat from COVID-19, satisfactions with health insurance, anticipatory flight anxiety, annual frequency of travel, extraversion, agreeableness, conscientiousness, neuroticism, intellect/imagination, risk taking, affect, level of disgust, and level of fear. It is identified that the variance is based on several characteristics of passengers and this variance is found to be $67 \%$ for business travel and $\% 66$ for pleasure travel. The most significant factors that decreases willingness to fly for business purposes are: perceived threat from COVID19, agreeableness, propensity of risk taking, affect, and fear. The most significant factors decreasing willingness to fly for pleasure are the same with the factors of business purposes, except propensity of risk taking. 


\section{Conclusion}

As a result of the study, it is predicted that there will be a decrease in the domestic flights in Turkey, which is inversely proportional to an increase in declared average number of patients. It is also predicted that it will return to normal even in the first year in case of pandemic ends. When the effects of various variables are examined, it is revealed that all other socio-demographic variables except education level are determinative in the change of flight frequency.

The findings obtained from this study can help airline companies, tourism industry and other related parties in their planning for up to one year by providing a prediction opportunity for demand by looking the estimated average daily numbers of patients and other variables that are determined to be effective.

Our study has some limitations. First, it is limited to Turkish domestic flights. This was preferred lest many different uncontrollable variables adversely affect the accuracy of the results. Then, it is limited with the number of participants and it is assumed that they answer the questionary honestly. Furthermore, there are so many factors influencing the travelling decision of airline passengers, but the aim of the survey is mainly identifying the flight frequency decisions of passengers based on daily patient numbers of COVID19 , which is found to be really determinative on their decisions. Though the findings of the paper about flight frequency changes give insights about the recovery of demand to air travel, it doesn't mean that air transportation industry will recover in line with the results of the survey, since the recovery of the air transportation industry doesn't depend only on passenger demand but also many other factors. For example, any kind of necessary restrictions imposed by authorities for reducing the spreading of pandemic limits the number of flights in any country independent of passenger demand size, resulting in a contraction in air transportation industry. However, if the method of this study is used to gather data in any location, extent and time; and feeded with the data obtained from the models which predicts pandemic spreading, it may be a very useful input resource especially for the models that predict recovery time of air transportation industry. 


\section{Appendix}

Table 9 The percentages, averages and standard deviations of the responses related to annual flight frequencies varying according to demographic factors

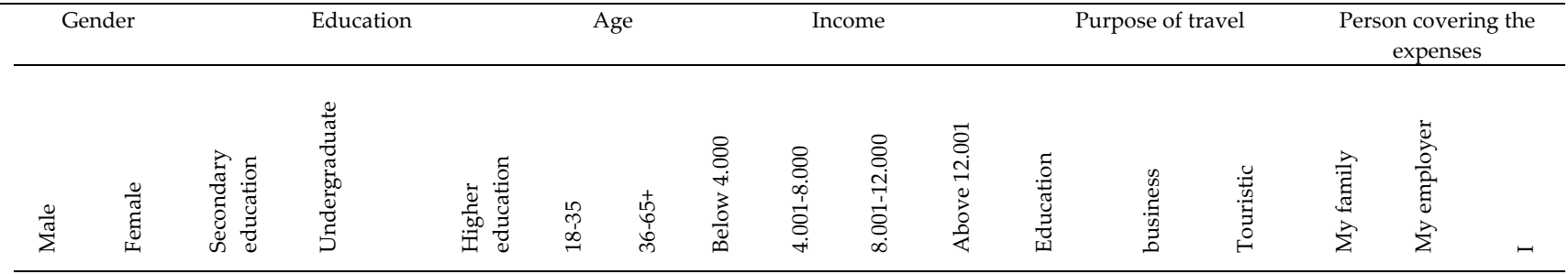

\section{A7-Number}

of annual

flights before

the pan-

demic

$1-3(\%)$

4-6 $(\%)$

$7-9(\%)$

42,3

44,4

$\begin{array}{lllllll}36,5 & 46,9 & 78,1 & 46,2 & 45,6 & 19,7 & 14,3\end{array}$

$14,3 \quad 39,1$

$\begin{array}{lllll}9,1 & 45,6 & 66,7 & 29,4 & 44,2\end{array}$

$33,3 \quad 27,1$

33,3

30,3

33,3

$10+(\%)$

$26,5 \quad 10$

$-$

5,6
21,8

3,7
18,5

$31,1 \quad 31,2 \quad 21,9 \quad 34,6 \quad 31,6 \quad 32,8$

85,7

$17,4 \quad 32,9$

$33,3 \quad 29,4 \quad 31,4$

Standard

Deviation

$3.97 \quad 3.14$

3.88

3.86

$27 \quad 17,2$

$\begin{array}{ccc}5,8 & 3,5 & 8,2\end{array}$

4,3
39,1

5,4
16,1

$2,9 \quad 5,8$

Average

3.7

$\begin{array}{lll}4.04 & 3.63 \quad 1.26\end{array}$

$3.38-3.76$

1.13

4.55

.

18,6

A8-12

months $=1500$

0 (\%)

$41,7 \quad 58,6 \quad 16,7$

55

$$
4.9
$$

4-6 (\%)

7-9 (\%)

$10+(\%)$

Standard

Deviation
Average

$\begin{array}{ccr}41,7 & 58,6 & 16,7 \\ 42,4 & 34,3 & 66,7 \\ 10,6 & 4,3 & - \\ 1,5 & - & 16,7 \\ 3,8 & 2,9 & - \\ & & \\ 2.65 & 2.26 & 2.73 \\ 2 & 1.2 & 2.7\end{array}$

45,8
40,1
10,6
0,7
2,8
2.41
1.7

$\begin{array}{ccccccc}55,6 & 39,2 & 52,3 & 34,4 & 42,3 & 52,6 & 54,1 \\ 35,2 & 39,2 & 39,8 & 59,4 & 48,1 & 31,6 & 29,5 \\ 3,7 & 12,2 & 6,2 & 6,2 & 5,8 & 8,8 & 11,5 \\ - & 1,4 & 0,8 & - & - & 1,8 & 1,6 \\ 5,6 & 8,1 & 0,8 & - & 3,8 & 5,3 & 3,3 \\ & & & & & & \\ 2.84 & 3.34 & 1.79 & 1.32 & 2.47 & 2.99 & 2.66 \\ 1.6 & 2.5 & 1.3 & 1.5 & 1.7 & 1.8 & 1.7\end{array}$

$\begin{array}{ccccccc}54,1 & 28,6 & 45,7 & 49 & 58,3 & 50 & 46,2 \\ 29,5 & 57,1 & 39,1 & 38,9 & 33,3 & 41,2 & 39,7 \\ 11,5 & 14,3 & 6,5 & 8,7 & 8,3 & 2,9 & 9,6 \\ 1,6 & - & 2,2 & 0,7 & - & - & 1,3 \\ 3,3 & - & 6,5 & 2,7 & - & 5,9 & 3,2 \\ & & & & & & \\ 2.66 & 1.68 & 3.15 & 2.35 & 1.56 & 2.88 & 2.52 \\ 1.7 & 1.9 & 2.1 & 1.6 & 1.1 & 1.7 & 1.8\end{array}$




\begin{tabular}{|c|c|c|c|c|c|c|c|c|c|c|c|c|c|c|c|c|c|}
\hline \multicolumn{18}{|c|}{ A9-6 months } \\
\hline $0(\%)$ & 34,1 & 45,7 & 16,7 & 36,6 & 44,4 & 28,4 & 43,8 & 28,1 & 34,6 & 43,9 & 41 & 28,6 & 32,6 & 40,3 & 41,7 & 35,3 & 38,5 \\
\hline $1-3(\%)$ & 46,2 & 44,3 & 50 & 48,6 & 37 & 43,2 & 46,9 & 59,4 & 55,8 & 33,3 & 41 & 42,9 & 47,8 & 45 & 50 & 52,9 & 43,6 \\
\hline $4-6(\%)$ & 14,4 & 7,1 & 16,7 & 11,3 & 13 & 18,9 & 7,8 & 12,5 & 5,8 & 15,8 & 13,1 & 28,6 & 10,9 & 11,4 & 8,3 & 5,9 & 13,5 \\
\hline $7-9(\%)$ & 1,5 & - & 16,7 & 0,7 & - & 1,4 & 0,8 & - & - & 1,8 & 1,6 & - & 2,2 & 0,7 & - & - & 1,3 \\
\hline $10+(\%)$ & 3,8 & 2,9 & - & 2,8 & 5,6 & 8,1 & 0,8 & - & 3,8 & 5,3 & 3,3 & - & 6,5 & 2,7 & - & 5,9 & 3,2 \\
\hline \multicolumn{18}{|l|}{ Standard } \\
\hline Deviation & 2.65 & 2.29 & 2.86 & 2.36 & 2.94 & 3.28 & 1.81 & 1.51 & 2.42 & 3.03 & 2.61 & 2.06 & 3.1 & 2.36 & 1.51 & 2.84 & 2.54 \\
\hline \multicolumn{18}{|l|}{$\begin{array}{l}\text { A10-6 } \\
\text { months }\end{array}$} \\
\hline $0(\%)$ & 65,9 & 81,4 & 66,7 & 69,7 & 75,9 & 67,6 & 73,4 & 87,5 & 61,5 & 71,9 & 70,5 & 57,1 & 67,4 & 73,2 & 91,7 & 67,6 & 70,5 \\
\hline $1-3(\%)$ & 22,7 & 11,4 & 33,3 & 19,7 & 14,8 & 13,5 & 21,9 & 12,5 & 30,8 & 15,8 & 14,8 & 42,9 & 19,6 & 17,4 & 8,3 & 23,5 & 18,6 \\
\hline $4-6(\%)$ & 9,8 & 4,3 & - & 9,9 & 3,7 & 13,5 & 4,7 & - & 3,8 & 10,5 & 13,1 & - & 8,7 & 8,1 & - & - & 10,3 \\
\hline 7-9 (\%) & - & 1,4 & - & - & 1,9 & 1,4 & - & - & 1,9 & - & - & - & 2,2 & - & - & 2,9 & - \\
\hline $10+(\%)$ & 1,5 & 1,4 & - & 0,7 & 3,7 & 4,1 & - & - & 1,9 & 1,8 & 1,6 & - & 2,2 & 1,3 & - & 5,9 & 0,6 \\
\hline \multicolumn{18}{|l|}{ Standard } \\
\hline Average & 1.1 & 0.7 & 0.7 & 1 & 1.1 & 1.5 & 0.7 & 0.2 & 1.2 & 1.1 & 1.1 & 0.9 & 1.3 & 0.9 & 0.2 & 1.4 & 1 \\
\hline \multicolumn{18}{|c|}{$\begin{array}{l}\text { A11-12 } \\
\text { months }>3000\end{array}$} \\
\hline $0(\%)$ & 65,2 & 80 & 66,7 & 68,3 & 75,9 & 64,9 & 73,4 & 87,5 & 61,5 & 70,2 & 68,9 & 57,1 & 69,6 & 71,1 & 91,7 & 70,6 & 68,6 \\
\hline $1-3(\%)$ & 22,7 & 12,9 & 16,7 & 21,1 & 14,8 & 16,2 & 21,1 & 12,5 & 30,8 & 17,5 & 14,8 & 42,9 & 15,2 & 19,5 & 8,3 & 20,6 & 19,9 \\
\hline $4-6(\%)$ & 10,6 & 5,7 & 16,7 & 9,9 & 5,6 & 14,9 & 5,5 & - & 5,8 & 10,5 & 14,8 & - & 13 & 8,1 & - & 2,9 & 10,9 \\
\hline 7-9 (\%) & - & - & - & - & - & - & - & - & - & - & - & - & - & - & - & - & - \\
\hline $10+(\%)$ & 1,5 & 1,4 & - & 0,7 & 3,7 & 4,1 & - & - & 1,9 & 1,8 & 1,6 & - & 2,2 & 1,3 & - & 5,9 & 0,6 \\
\hline \multicolumn{18}{|l|}{ Standard } \\
\hline Deviation & 2.1 & 1.88 & 2.04 & 1.83 & 2.53 & 2.81 & 1.32 & 0.67 & 2.06 & 2.18 & 2.28 & 1.07 & 2.37 & 1.96 & 0.58 & 2.95 & 1.85 \\
\hline Average & 1.2 & 0.7 & 1.2 & 1 & 1 & 1.6 & 0.7 & 0.2 & 1.1 & 1.1 & 1.2 & 0.9 & 1.2 & 1 & 0.2 & 1.3 & 1 \\
\hline \multicolumn{18}{|c|}{$\begin{array}{l}\text { A12-6 } \\
\text { months }<750\end{array}$} \\
\hline $0(\%)$ & 21,2 & 20 & - & 19 & 27,8 & 13,5 & 25 & 15,6 & 21,2 & 21,1 & 23 & - & 17,4 & 22,8 & 41,7 & 14,7 & 20,5 \\
\hline $1-3(\%)$ & 47,7 & 64,3 & 50 & 54,9 & 50 & 50 & 55,5 & 65,6 & 50 & 54,4 & 49,2 & 71,4 & 54,3 & 52,3 & 50 & 61,8 & 51,9 \\
\hline $4-6(\%)$ & 24,2 & 12,9 & 33,3 & 21,1 & 16,7 & 27 & 16,4 & 18,8 & 25 & 17,5 & 19,7 & 28,6 & 15,2 & 21,5 & 8,3 & 8,8 & 23,7 \\
\hline
\end{tabular}

\section{0 idealkent}


The Effect of COVID-19 Pandemic on the Frequency of Domestic Flights

\begin{tabular}{|c|c|c|c|c|c|c|c|c|c|c|c|c|c|c|c|c|c|}
\hline 7-9 (\%) &, 08 & 1,4 & - & 0,7 & 1,9 & 2,7 & - & - & 1,9 & 1,8 & - & - & 2,2 & 0,7 & - & 2,9 & 0,6 \\
\hline $10+(\%)$ & 6,1 & 0.014 & 16,7 & 4,2 & 3,7 & 6,8 & 3,1 & - & 1,9 & 5,3 & 8,2 & - & 10,9 & 2,7 & - & 11,8 & 3,2 \\
\hline \multicolumn{18}{|l|}{ Standard } \\
\hline Deviation & 2.92 & 1.98 & 3.88 & 2.58 & 2.63 & 2.99 & 2.36 & 1.52 & 2.33 & 2.81 & 3.19 & 1.46 & 3.5 & 2.36 & 1.51 & 3.58 & 2.45 \\
\hline Average & 3 & 2.2 & 4.7 & 2.7 & 2.4 & 3.4 & 2.3 & 2.2 & 2.6 & 2.7 & 3 & 2.9 & 3.3 & 2.5 & 1.4 & 3.3 & 2.7 \\
\hline \multicolumn{18}{|c|}{$\begin{array}{l}\text { A13-12 } \\
\text { months }<750\end{array}$} \\
\hline $0(\%)$ & 20,5 & 18,6 & - & 17,6 & 27,8 & 13,5 & 23,4 & 15,6 & 21,2 & 19,3 & 21,3 & - & 17,4 & 21,5 & 41,7 & 14,7 & 19,2 \\
\hline $4-6(\%)$ & 20,5 & 18,6 & 50 & 19 & 18,5 & 31,1 & 13,3 & 28,1 & 23,1 & 17,5 & 14,8 & 14,3 & 15,2 & 21,5 & - & 8,8 & 23,7 \\
\hline 7-9 (\%) & 3,8 & 4,3 & - & 4,2 & 3,7 & 2,7 & 4,7 & - & 3,8 & 3,5 & 6,6 & - & 2,2 & 4,7 & - & 2,9 & 4,5 \\
\hline $10+(\%)$ & 6,8 & 1,4 & 16,7 & 4,9 & 3,7 & 8,1 & 3,1 & 3,1 & 1,9 & 5,3 & 8,2 & - & 10,9 & 3,4 & 8,3 & 11,8 & 3,2 \\
\hline \multicolumn{18}{|l|}{ Standard } \\
\hline Deviation & 3.11 & 2.26 & 3.66 & 2.83 & 2.76 & 3.14 & 2.59 & 2.4 & 2.42 & 2.87 & 3.38 & 1.13 & 3.5 & 2.68 & 3.3 & 3.58 & 2.63 \\
\hline Average & 3.1 & 2.6 & 5.2 & 3 & 2.6 & 3.6 & 2.5 & 2.8 & 2.7 & 2.9 & 3.2 & 2.4 & 3.3 & 2.8 & 2 & 3.3 & 2.9 \\
\hline \multicolumn{18}{|l|}{$\begin{array}{l}\text { A14-6 } \\
\text { months_0 }\end{array}$} \\
\hline $0(\%)$ & 3 & 2,9 & - & 2,1 & 5,6 & - & 4,7 & - & 1,9 & 5,3 & 3,3 & - & 2,2 & 3,4 & - & 2,9 & 3,2 \\
\hline 4-6 (\%) & 43,9 & 22,9 & 50 & 35,9 & 37 & 40,5 & 34,4 & 34,4 & 40,4 & 35,1 & 36,1 & 57,1 & 30,4 & 37,6 & 16,7 & 26,5 & 40,4 \\
\hline $7-9(\%)$ & 5,3 & 7,1 & - & 7 & 3,7 & 6,8 & 5,5 & - & 3,8 & 5,3 & 11,5 & - & 4,3 & 6,7 & - & 2,9 & 7,1 \\
\hline $10+(\%)$ & 10,6 & 8,6 & - & 9,9 & 11,1 & 13,5 & 7,8 & - & 9,6 & 8,8 & 16,4 & - & 21,7 & 6,7 & - & 26,5 & 7,1 \\
\hline \multicolumn{18}{|l|}{ Standard } \\
\hline Deviation & 3.12 & 3.13 & 1.64 & 3.13 & 3.28 & 3.3 & 2.99 & 1.45 & 3.05 & 3.1 & 3.6 & 1.6 & 3.94 & 2.85 & 1.17 & 4.23 & 2.87 \\
\hline Average & 4.6 & 3.9 & 3.5 & 4.4 & 4.3 & 5 & 4 & 3 & 4.4 & 4.1 & 5.3 & 3.7 & 5.3 & 4.1 & 2.5 & 5.6 & 4.3 \\
\hline \multicolumn{18}{|l|}{$\begin{array}{l}\text { A15-12 } \\
\text { months_0 }\end{array}$} \\
\hline $0(\%)$ & - & - & - & - & - & - & - & - & - & - & - & - & - & - & - & - & - \\
\hline $1-3(\%)$ & 26,5 & 52,9 & 33,3 & 34,5 & 38,9 & 25,7 & 41,4 & 50 & 38,5 & 40,4 & 21,3 & 42,9 & 34,8 & 35,6 & 66,7 & 35,3 & 33,3 \\
\hline $4-6(\%)$ & 37,9 & 25,7 & 50 & 35,9 & 25,9 & 40,5 & 29,7 & 46,9 & 34,6 & 28,1 & 31,1 & 57,1 & 15,2 & 38,3 & 25 & 17,6 & 37,8 \\
\hline 7-9 (\%) & 12,1 & 7,1 & - & 9,9 & 13 & 5,4 & 13,3 & - & 11,5 & 8,8 & 16,4 & - & 10,9 & 10,7 & - & 8,8 & 11,5 \\
\hline $10+(\%)$ & 23,5 & 14,3 & 16,7 & 19,7 & 22,2 & 28,4 & 15,6 & 3,1 & 15,4 & 22,8 & 31,1 & - & 39,1 & 15,4 & 8,3 & 38,2 & 17,3 \\
\hline \multicolumn{18}{|l|}{ Standard } \\
\hline Deviation & 3.69 & 3.53 & 3.66 & 3.65 & 3.9 & 3.87 & 3.55 & 2.13 & 3.49 & 3.93 & 3.84 & 1.6 & 4.43 & 3.42 & 2.97 & 4.44 & 3.51 \\
\hline Average & 6.2 & 4.6 & 5.2 & 5.6 & 5.8 & 6.4 & 5.2 & 3.7 & 5.3 & 5.6 & 7 & 3.7 & 7 & 5.3 & 3.6 & 6.9 & 5.6 \\
\hline
\end{tabular}

idealkent 1331 


\section{References}

Adrienne, N., Budd, L., \& Ison, S. (2020). Grounded aircraft: An airfield operations perspective of the challenges of resuming flights post Covid. Journal of Air Transport Management, 89 , 101921. https://doi.org/10.1016/j.jairtraman.2020.101921

Air traffic will take years to return to 2019 levels. (2020, July 8). Retrieved September 25, 2021, from https://dailybrief.oxan.com/Analysis/DB253776/Air-traffic-will-takeyears-to-return-to-2019-levels

Altınay Özdemir, M. (2020). How covid-19 outbreak affects tourists' travel intentions? A case study in Turkey. Social Mentality And Researcher Thinkers Journal, 6(32), 1101-1113. https://doi.org/10.31576/smryj.562

Büyüköztürk, Ş. (2018). Sosyal bilimler için veri analizi el kitabı (28th ed.). Ankara, Turkey: Pegem Akademi Yayınları.

Coronavirus disease (COVID-19). (2020, Dec). Retrieved June 27, 2021, from https://www.who.int/emergencies/diseases/novel-coronavirus-2019

Di Renzo, L., Gualtieri, P., Pivari, F., Soldati, L., Attinà, A., Cinelli, G., De Lorenzo, A. (2020). Eating habits and lifestyle changes during Covid-19 lockdown: An Italian survey. Journal of Translational Medicine, 18(1). https://doi.org/10.1186/s12967-02002399-5

Gallego, I., \& Font, X. (2020). Changes in air passenger demand as a result of the Covid19 crisis: Using big data to inform tourism policy. Journal of Sustainable Tourism, 29(9), 1470-1489. https://doi.org/10.1080/09669582.2020.1773476

Gerede, E. (2015). Havayolu taşımacılığı ve ekonomik düzenlemeler teori ve Türkiye uygulamasi [Pdf] (1st ed., Vol. 1). Retrieved from http://web.shgm.gov.tr/documents/sivilhavacilik/files/pdf/kurumsal/yayinlar/S HGM_Havayolu_Tasimaciligi_Kitabi.pdf

Gudmundsson, S., Cattaneo, M., \& Redondi, R. (2021b). Forecasting temporal world recovery in air transport markets in the presence of large economic shocks: The case of Covid-19. Journal of Air Transport Management, 91, 102007. https://doi.org/10.1016/j.jairtraman.2020.102007

ICAO. (2020, May 15). icao.int. Retrieved October 15, 2020, from https:/www.icao.int/sustainability/Documents/COVID19/ICAO_Coronavirus_Econ_Impact.pdf

İstatistikler. (2020, Nov.). Retrieved November 10, 2020, from https://www.dhmi.gov.tr/Sayfalar/Istatistikler.aspx

Lamb, T. L., Winter, S. R., Rice, S., Ruskin, K. J., \& Vaughn, A. (2020). Factors that predict passengers willingness to fly during and after the Covid-19 pandemic. Journal of $\begin{array}{llll}\text { Air Transport } & 101897 .\end{array}$ https://doi.org/10.1016/j.jairtraman.2020.101897 
Lin, Y. H., \& Zhang, C. (2021). Investigating air travellers' travel motivation during a pandemic crisis. Journal of Air Transport Management, 97, 102138. https://doi.org/10.1016/j.jairtraman.2021.102138

Rockland, D. B. (2020). Air traveler response to Covid 19 An 11 country survey: Wave III. Retrieved October 15, 2020, from https://www.iata.org/contentassets/5f8235a4ef364ec886ad2594531c04d0/covid19-survey-press-briefing-presentation-.pdf

Suau-Sanchez, P., Voltes-Dorta, A., \& Cugueró-Escofet, N. (2020). An early assessment of the impact of Covid-19 on air transport: Just another crisis or the end of aviation as we know it? Journal of Transport Geography, 86, 102749. https://doi.org/10.1016/j.jtrangeo.2020.102749

Sun, X., Wandelt, S., \& Zhang, A. (2020). How did Covid-19 impact air transportation? A first peek through the lens of complex networks. Journal of Air Transport Management, 89, 101928. https://doi.org/10.1016/j.jairtraman.2020.101928

Sun, X., Wandelt, S., Zheng, C., \& Zhang, A. (2021). Covid-19 pandemic and air transportation: Successfully navigating the paper hurricane. Journal of Air $\begin{array}{lll}\text { Transport Management, } & 102062 .\end{array}$ https://doi.org/10.1016/j.jairtraman.2021.102062

Ye, J. (2020, July 4). Scenarios for a post-Covid-19 world airline network. Retrieved September 21, 2021, from https://arxiv.org/abs/2007.02109 